\title{
Development of RNAi in Insects and RNAi-Based Pest Control
}

\author{
Guang Yang1, Minsheng You ${ }^{1 *}$, Liette Vasseur ${ }^{1,2}$, \\ Yiying Zhao ${ }^{3}$ and Chunhui Liu ${ }^{1}$ \\ ${ }^{1}$ Institute of Applied Ecology, Fujian Agriculture and Forestry University \\ ${ }^{2}$ Department of Biological Sciences, Brock University \\ ${ }^{3}$ College of Agriculture, Shihezi University \\ ${ }^{1,3}$ China \\ ${ }^{2}$ Canada
}

\section{Introduction}

In agricultural systems, insect pests can cause crop damage mainly through loss in yield or quality resulting in a loss in profits for farmers. Worldwide pests cost billions of dollars due to damage and use of pesticides. Chemical pesticides are still the major approach for controlling insect pests, but they are associated with significant hazards to the environment and human health. The alternative commercial biotechnological system relies mostly on the expression of Bacillus thuringiensis insecticidal proteins (Cry toxins). Its effectiveness however is threatened by the development of resistance in some species such as Ostrinia nubilalis (Lepidoptera, Pyralidae) and Heliothis virescens (Lepidoptera: Noctuidae) (Ferre and Van Rie, 2002; Baum et al., 2007). As a result, there is an urgent need to develop economically and ecologically sound alternatives for pest control.

Gene silencing has been suggested as one of the new alternatives to reduce damage from insect pests. RNA interference (RNAi) is first described by Fire et al. (1998), and its mechanism lies in that a double-stranded RNA (dsRNA) introduced in an organism has the capacity to silence post-transcriptional genes (Hannon, 2002; Geley and Muller, 2004). RNAi is highly conserved in eukaryotic organisms (Fire, 2007). It is considered as a specific type of defence mechanism (Terenius et al., 2011). Four different types of RNAi have been described including short interfering RNAs (siRNAs), piwi-interacting RNAs (piRNAs), endogenous siRNAs (endo-siRNAs or esiRNAs), and microRNAs (miRNAs) (Terenius et al., 2011). To date, RNAi has been proven promising for research on gene function determination and gene knockdown in eukaryotes and medical control of cancers and viral disease (Huvenne and Smagghe, 2010).

In insects, studies have mainly targeted the understanding of the RNAi mechanism, and the function, regulation and expression of genes. Introduction of dsRNA into an organism has been tested by using different techniques such as microinjection (Bettencourt et al., 2002;

\footnotetext{
${ }^{1}$ These authors contributed equally to this chapter.

* Corresponding author: msyou@iae.fjau.edu.cn
} 
Tomoyasu and Denell, 2004; Ghanima et al, 2007), soaking, or, most preferably, oral feeding of artificial diet (Eaton et al., 2002; Turner et al., 2006; Baum et al., 2007; Mao et al., 2007; Chen et al., 2008; Tian et al., 2009). Transgenic plants producing dsRNAs directed against genes function in Lepidoptera, Coleoptera, and Hemiptera pests are becoming more common (Gordon and Waterhouse, 2007; Baum et al., 2007; Mao et al., 2007, Chen et al., 2010). For example, Chen et al. (2010) report the successful feeding of TPS (trehalose-6-phosphate synthase for the synthesis of trehalose, main sugar reserve in haemolymph) dsRNA solutions to silence this gene thus proposing it as a useful pest control agent. These results suggest that over time, new generations of insect-resistant crops will be created to manage agriculturally important insect pests.

In this review chapter, we summarize the current knowledge on the recent RNAi research on insects, including the application of RNAi techniques in research involving functional insect genes and functional genomics, the methods of dsRNA uptake RNAi in insects, the systemic diffusion of RNAi silencing molecules in the insect body and the mechanism underlying this diffusion, and the potential application of RNAi in integrated pest management (IPM). The main purpose of this review is to help entomologists become familiar with RNAi research, a rapidly growing field where new avenues and techniques are being used to investigate insect RNAi mechanisms for the development of pest control.

\section{Study on the function of insect genes using RNAi methods}

RNAi is a powerful tool for the study on the function of insect genes. It was first used in the study of a model insect, the fruit fly Drosophila melanogaster (Lipardi et al., 2001). RNAi studies in D. melanogaster have laid a solid foundation for the development of insect RNAi technology and the elucidation of the RNAi mechanisms in insects. Recently, Huvenne and Smagghe (2010) have reviewed the definitions of RNAi in insects while Terenius et al. (2011) have analyzed the variability and the implications of over 150 published and unpublished studies, mainly focusing the analysis on lepidopteran insects, on the need for further studies on RNAi mechanisms.

In this section, we discuss a selected group of published studies and the main orientations used by researchers in exploring these techniques. Table 1 summarizes the studied functions, methods used for RNAi introduction and the main responses of insects. Besides D. melanogaster, 20 other insect species are reported here, including 7 species of Lepidoptera, 3 species of Coleoptera, 3 species of Orthoptera, 2 species of Hymenoptera, 2 species of Homoptera, 1 species of Diptera, 1 species of Isoptera, and 1 species of Hemyptera. These selected papers have all in common the successful use of RNAi mechanisms as potential pest control agent. It is important to note that, except for a few exceptions (e.g. circadian clock gene), most studies have targeted different genes. Responses also greatly vary from minor effects such as disruption in functional rhythm to reduction in fitness and increased mortality. As reported by Terinius et al. (2011) for lepidopteran species, most of the studies have helped better understand developmental processes and the immune system.

\section{Internal diffusion of RNAi molecules within insect body}

The effects of RNAi inside the body of insects are determined by an important factor, the spread of silencing RNA molecules inside the insect body (so-called systemic RNAi). In 


\begin{tabular}{|c|c|c|c|}
\hline Insects & Genes and References & Methods & Effects \\
\hline \multirow[b]{2}{*}{$\begin{array}{l}\text { Silkworm } \\
\text { Bombyx mori }\end{array}$} & \begin{tabular}{|l|} 
Circadian clock gene per \\
(Sandrelli et al., 2007)
\end{tabular} & Transgenics & $\begin{array}{l}\text { Disruption of egg-hatching } \\
\text { rhythm }\end{array}$ \\
\hline & $\begin{array}{l}\text { Ecdysis-triggering } \\
\text { hormone gene ETH (Dai } \\
\text { et al., 2008) }\end{array}$ & Transgenics & $\begin{array}{l}\text { Lethal at pharate second-instar } \\
\text { larval stage }\end{array}$ \\
\hline \multirow{2}{*}{$\begin{array}{l}\text { Egyptian cotton } \\
\text { leafworm } \\
\text { Spodoptera } \\
\text { littoralis }\end{array}$} & $\begin{array}{l}\beta \text {-actin gene (Gvakharia et } \\
\text { al., 2003) }\end{array}$ & Injection & Disruption of sperm release \\
\hline & \begin{tabular}{|l|} 
Circadian clock gene per \\
(Kotwica et al., 2009)
\end{tabular} & Injection & Delayed sperm release \\
\hline $\begin{array}{l}\text { Light brown } \\
\text { apple moth } \\
\text { Epiphyas } \\
\text { postvittana }\end{array}$ & $\begin{array}{l}\text { Carboxylesterase gene } \\
\text { EposCXE1 and } \\
\text { pheromone binding } \\
\text { protein gene EposPBP1 } \\
\text { (Turner } \text { et al., 2006) }\end{array}$ & Feeding & Inhibition of gene expression \\
\hline \multirow{2}{*}{$\begin{array}{l}\text { Cotton } \\
\text { bollworm } \\
\text { Helicoverpa } \\
\text { armigera }\end{array}$} & $\begin{array}{l}\text { Cytochrome P450 gene } \\
\text { CYP6AE14 (Mao et al., } \\
\text { 2007) }\end{array}$ & Feeding & Inhibition of larval growth \\
\hline & $\begin{array}{l}\text { Glutathione-S-transferase } \\
\text { gene GST1 (Mao et al., } \\
\text { 2007) }\end{array}$ & Feeding & $\begin{array}{l}\text { Successful inhibition of gene } \\
\text { expression }\end{array}$ \\
\hline $\begin{array}{l}\text { Beet armyworm } \\
\text { Spodoptera exigua }\end{array}$ & $\begin{array}{l}\text { Chitin synthase gene } \\
\text { (Chen } \text { et al., 2008) }\end{array}$ & Injection & $\begin{array}{l}\text { Disorder in the insect cuticle, } \\
\text { no expansion of the larval } \\
\text { trachea epithelial wall, and } \\
\text { other larval abnormalities }\end{array}$ \\
\hline $\begin{array}{l}\text { Japanese pine } \\
\text { sawyer } \\
\text { Monochamus } \\
\text { alternatus }\end{array}$ & $\begin{array}{l}\text { Laccase gene MaLac2 } \\
\text { (Niu et al., 2008) }\end{array}$ & Injection & $\begin{array}{l}\text { Pupal and adult cuticle } \\
\text { sclerotisation, death at a high } \\
\text { dose }\end{array}$ \\
\hline \multirow[b]{2}{*}{$\begin{array}{l}\text { Red flour beetle } \\
\text { Tribolium } \\
\text { castaneum }\end{array}$} & $\begin{array}{l}\text { Chitin synthase genes } \\
\text { TcCHS1 and TcCHS2 } \\
\text { (Arakane et al., 2005) }\end{array}$ & Injection & $\begin{array}{l}\text { Disruption in all types of } \\
\text { moulting(larva-larva, larva- } \\
\text { pupa, and pupa-adult), } \\
\text { cessation of ingestion, decrease } \\
\text { in larval size, and reduction of } \\
\text { chitin content in the midgut }\end{array}$ \\
\hline & $\begin{array}{l}\text { Chitinase-like proteins } \\
\text { TcCHT5, TcCHT10, } \\
\text { TcCHT7, and TcIDGF4 } \\
\text { (Zhu et al., 2008) }\end{array}$ & Injection & $\begin{array}{l}\text { Effects on pupal-adult } \\
\text { moulting Effects on egg } \\
\text { hatching, larval moulting, } \\
\text { pupation, and adult } \\
\text { metamorphosis. } \\
\text { Effects on abdominal } \\
\text { contraction and wing/elytra } \\
\text { extension. Effects on adult } \\
\text { eclosion }\end{array}$ \\
\hline
\end{tabular}




\begin{tabular}{|c|c|c|c|}
\hline Insects & Genes and References & Methods & Effects \\
\hline \begin{tabular}{|l|} 
Western corn \\
rootworm \\
Diabrotica \\
virgifera virgifera \\
LeConte \\
\end{tabular} & $\begin{array}{l}\text { Vacuolar ATPase }(v-A T P) \\
\text { (Baum et al., 2007) }\end{array}$ & Feeding & $\begin{array}{l}\text { Delayed larval development } \\
\text { and increased mortality }\end{array}$ \\
\hline \begin{tabular}{|l|} 
Striped flea \\
beetle \\
Phyllotreta \\
striolata
\end{tabular} & $\begin{array}{l}\text { Arginine kinase gene } A K \\
\text { (Zhao et al., 2008) }\end{array}$ & Feeding & $\begin{array}{l}\text { Delayed development, } \\
\text { increased mortality, and } \\
\text { reduced fertility }\end{array}$ \\
\hline \multirow{2}{*}{$\begin{array}{l}\text { Mediterranean } \\
\text { field cricket } \\
\text { Gryllus } \\
\text { bimaculatus }\end{array}$} & $\begin{array}{l}\text { Circadian clock gene per } \\
\text { (Moriyama et al., 2008) }\end{array}$ & Injection & $\begin{array}{l}\text { Complete loss of circadian } \\
\text { control of locomotor activity } \\
\text { and electrical activity in the } \\
\text { optic lobe }\end{array}$ \\
\hline & $\begin{array}{l}\text { Nitric oxide synthase } \\
\text { gene NOS } \\
\text { (Takahashi } \text { et al., 2009) }\end{array}$ & Injection & $\begin{array}{l}\text { Destruction of long-term } \\
\text { memory }\end{array}$ \\
\hline \multirow{2}{*}{$\begin{array}{l}\text { German } \\
\text { cockroach } \\
\text { Blattella } \\
\text { germanica }\end{array}$} & $\begin{array}{l}\text { BgRXR gene (Martin et } \\
\text { al., 2006) }\end{array}$ & Injection & Inhibition of pupal eclosion \\
\hline & $\begin{array}{l}\text { Pigment-dispersing factor } \\
\text { gene } p d f \text { (Lee } \text { et al., 2009) }\end{array}$ & Injection & Effects on insect night activity \\
\hline $\begin{array}{l}\text { American } \\
\text { grasshopper } \\
\text { Schistocerca } \\
\text { americana }\end{array}$ & $\begin{array}{l}\text { Eye colour gene vermilion } \\
\text { (Dong and Friedrich, } \\
\text { 2005) }\end{array}$ & Injection & $\begin{array}{l}\text { Suppression of ommochrome } \\
\text { formation and systematic } \\
\text { expression }\end{array}$ \\
\hline $\begin{array}{l}\text { Brown } \\
\text { planthopper } \\
\text { Nilaparvata } \\
\text { lugens }\end{array}$ & $\begin{array}{l}\text { Trehalose phosphate } \\
\text { synthase (TPS) (NITPS } \\
\text { mRNA) (Chen et al., 2010) }\end{array}$ & Feeding & $\begin{array}{l}\text { Disturbed development } \\
\text { through disruption in the TPS } \\
\text { enzymatic activity, reduction } \\
\text { of insect survival rate }\end{array}$ \\
\hline $\begin{array}{l}\text { Turnip sawfly } \\
\text { Athalia rosae }\end{array}$ & $\begin{array}{l}\text { Ar white gene (Sumitani et } \\
\text { al., 2005) }\end{array}$ & Injection & $\begin{array}{l}\text { White phenocopy in } \\
\text { embryonic eye } \\
\text { pigmentation }\end{array}$ \\
\hline $\begin{array}{l}\text { European honey } \\
\text { bee } \\
\text { Apis mellifera }\end{array}$ & $\begin{array}{l}\text { Transcription factor gene } \\
\text { Relish (Schlüns and } \\
\text { Crozier, 2007) }\end{array}$ & Injection & $\begin{array}{l}\text { Inhibition of Relish gene } \\
\text { expression and reduction in } \\
\text { the expression of two other } \\
\text { immune genes, abaecin and } \\
\text { hymenoptaecin }\end{array}$ \\
\hline $\begin{array}{l}\text { Triatomid bug } \\
\text { Rhodnius prolixus }\end{array}$ & $\begin{array}{l}\text { Salivary nitrophorin } 2 \\
\text { gene NP2 } \\
\text { (Araujo et al., 2006) } \\
\end{array}$ & $\begin{array}{l}\text { Injection } \\
\text { and } \\
\text { feeding } \\
\end{array}$ & $\begin{array}{l}\text { Shortened plasma coagulation } \\
\text { time }\end{array}$ \\
\hline $\begin{array}{l}\text { Savannah tsetse } \\
\text { fly } \\
\text { Glossina } \\
\text { morsitans } \\
\text { morsitans } \\
\end{array}$ & $\begin{array}{l}\text { TsetseEP gene and } \\
\text { transferrin gene 2A192 } \\
\text { (Walshe } \text { et al., 2009) }\end{array}$ & Feeding & $\begin{array}{l}\text { Inhibition of TsetseEP gene } \\
\text { expression, but no inhibition of } \\
\text { 2A192 gene expression }\end{array}$ \\
\hline
\end{tabular}




\begin{tabular}{|c|c|c|c|}
\hline Insects & Genes and References & Methods & Effects \\
\hline $\begin{array}{l}\text { Eastern } \\
\text { subterranean } \\
\text { termite } \\
\text { Reticulitermes } \\
\text { flavipes }\end{array}$ & $\begin{array}{l}\text { Cellulase enzyme gene } \\
\text { Cell-1 and caste- } \\
\text { regulatory hexamerin } \\
\text { storage protein gene Hex- } \\
2 \text { (Zhou et al., 2008) }\end{array}$ & Feeding & $\begin{array}{l}\text { Reduction in group fitness and } \\
\text { increased mortality }\end{array}$ \\
\hline
\end{tabular}

Table 1. RNAi research on functional genes in insects

plants, the nematode Caenorhabditis elegans, and the planarian Schmidtea mediterranea, RNAi is systemic as the RNAi signal spreads throughout the entire biological system by travelling between cells (Fire et al., 1998; Newmark et al., 2003). In insects, RNAi is not always to be systemic. For example, fly cells take up dsRNA, which cannot spread throughout the entire body (Saleh et al., 2006). Whangbo and Hunter (2008) have defined different mechanisms for dsRNA uptake: cell-autonomous and non-cell autonomous. Huvenne and Smagghe (2010) described these two types of RNAi and their level of spread which would be greater in systemic non-cell autonomous RNAi than in the cell autonomous RNAi. While most research in insects has been conducted with cell-autonomous RNAi, it is suggested that studies should focus towards non-cell autonomous RNAi as a better potential for defining agent of insect control.

In summary, studies have shown that the ability to distribute an RNAi signal is different in different insects. The intake of dsRNA by Drosophila cells leads to localised gene silencing, without systemic distribution of the RNAi signal (Van Roessel et al., 2002; Roignant et al., 2003; Dietzl et al., 2007). On the other end, Tribolium (Tomoyasu et al., 2008) and Schistocerca americana (Dong and Friedrich, 2005) have strong systemic RNAi reactions. The gene responsible for nematode systemic RNAi is sid-1 (Winston et al., 2002). Correspondingly, the sid-1 gene is not found in the Drosophila genome, whereas the grasshopper has a sid-1 ortholog (Dong and Friedrich, 2005), and Tribolium also has a sid-1-like gene (Tomoyasu et al., 2008). Further BLAST searches at the NCBI website have identified one species in Coleoptera, one in Lepidoptera, two in Hymenoptera, and three in Hemiptera containing sid-1 homologs, whereas no homologous gene has been found in Homoptera (Walshe et al., 2009).

Further studies have found that the RNAi mechanisms in Tribolium and the nematode C. elegans are different. Tribolium does not have some of the key elements that are required for RNAi in C. elegans, such as RNA-dependent RNA polymerase (RdRP) and the RNA channel transporter (SID) (Fire et al., 1998; Winston et al., 2002). Furthermore, the function of the sid-1like gene of Tribolium is not to absorb RNAi but, instead, is similar to the function of the tag130 gene of C. elegans (Tomoyasu et al., 2008). Therefore, further verification is needed to define the function of the sid-1 gene in insect RNAi. Recent studies have shown that the anti-viral RNAi reaction in Drosophila depends on a virus-specific immune signal and systemic spreading (Saleh et al., 2009). Further studies need to be conducted to understand the spread of silencing RNA within the insect body and the genes involved in this process. Understanding and revealing the molecular mechanisms of determining how RNA spreads systemically inside the insect body will facilitate the application of RNAi technology for pest control.

\section{Methodology of dsRNA uptake in insects}

Methods of dsRNA uptake in insects can greatly vary and strongly influence the efficiency of gene silencing, thus their potential as insect pest control agent. It is important to note that 
since gene silencing is only limited to cells that are infected, the main challenge is the selection of the delivery system (Terenius et al., 2011). In both types, methods of delivery must be first defined, being effectively easier and better understood for cell-autonomous RNAi machinery (Siomi and Siomi, 2009). The main uptake (or delivery) methods include injection, soaking, feeding, transgenic technique, and viral infection. This section examines these various mechanisms and their effectiveness in delivering RNAi and gene silencing in various species.

\subsection{Microinjection}

Microinjection, i.e. the direct injection of dsRNA into the body of insects, has been one of the most effective delivery methods for systemic RNAi types. Short dsRNA have had the most success with this mechanism (Siomi and Siomi, 2009). In addition, the $5^{\prime}$ end of the dsRNA can affect the effectiveness of RNAi; a phosphorylated $5^{\prime}$ end exhibits better gene silencing rate than does a hydroxylated 5' end (Boutla et al., 2001).

The major advantage of injecting dsRNA into the insect body is the high efficiency of inhibiting gene expression. There are however some limitations with micro-injection. First, the cost for in vitro synthesis and storage of dsRNA is relatively high, and the steps are complicated. In addition, injection pressure and the wound generated inevitably affect the insects. It has been shown that skin damage stimulates the immune response. In practice, this delivery method would have very limited application as pest control agent.

\subsection{Soaking}

Soaking $D$. melanogaster embryos in a dsRNA solution can inhibit gene expression, and its effectiveness is comparable to the injection method in that it requires a higher concentration of dsRNA (Eaton et al., 2002). Soaking D. melanogaster S2 cells in CycE and ago dsRNA solutions has been shown to effectively inhibit the expression of these two genes for cell cycle, thereby elevating levels of protein synthesis (March and Bentley, 2007). The soaking method is suitable only for certain insect cells and tissues as well as for specific insects of developmental stages that readily absorb dsRNA from the solution, and therefore, it is rarely used.

\subsection{Feeding of artificial diet}

Compared to other methods, dsRNA feeding is the most attractive primarily because it is convenient and easy to manipulate. Since it is a more natural method of introducing dsRNA into insect body, it causes less damage to the insect than microinjection (Chen et al., 2010). It is especially popular in very small insects that are more difficult to manipulate using microinjection. Early insect RNAi feeding studies were frustrating; for example, the injection of dsRNA effectively silenced the aminopeptidase gene slapn, which is expressed in the midgut of Spodoptera littoralis, but feeding with dsRNA did not achieve RNAi (Rajagopal et al., 2002).

Fortunately, there are other studies showing that dsRNA feeding can be successful for RNAi studies in insects. Feeding dsRNA to E. postvittana larvae has been shown to inhibit the expression of the carboxylesterase gene EposCXE1 in the larval midgut and also to inhibit the expression of the pheromone-binding protein EposPBP1 in adult antennae (Turner et al., 2006). dsRNA feeding also inhibite the expression of the nitrophorin 2 (NP2) gene in the salivary gland of Rhodnius prolixus, leading to a shortened coagulation time of plasma 
(Araujo et al., 2006). dsRNA feeding has also been successful in many other insects, including insects of the orders Hemiptera, Coleoptera, and Lepidoptera (Baum et al., 2007; Mao et al., 2007).

The main challenge remains that there needs to be a greater amount of material for delivery as silencing has been shown to be incomplete (Chen et al., 2010). This phenomenon has been observed after ingestion of CELL-1 dsRNA by the termite Reticulitermes flavipes (Zhou et al., 2008), TPS dsRNA in N. lugens nymphae (Chen et al. 2010), Nitrophorin 2 dsRNA by Rhodnius prolixus (Araujoa et al., 2006). In addition, different species of insects have different sensitivities to RNAi molecules when delivered orally. For example, Glossina morsitans fed with dsRNA may effectively inhibit the expression of TsetseEP in the midgut, but cannot inhibit the expression of the transferrin gene 2A192 in fat bodies due to lack of transfer capacity between tissues (Walshe et al., 2009). The mechanisms associated with the transfer of gene expression through feeding delivery method still need further study.

In addition, one method that may be better than direct feeding with dsRNA is the use of transgenic plants to produce dsRNA (Baum et al., 2007; Mao et al., 2007). The advantage of this method is the generation of continuous and stable dsRNA material. Genetically engineered dsRNA-producing yeast strains have also been developed to feed D. melanogaster, but gene silencing was not successful (Gura, 2000). However, dsRNA produced in bacteria is effective in C. elegans (Timmons and Fire, 1998). Therefore, the use of bacteria, especially insecticidal microorganisms, to produce dsRNA for insect RNAi merits further study.

\subsection{Developing transgenic insects}

The advantage of using transgenic insects that carry the dsRNA is that as it is inheritable, the expression can be stable and continuous. The technique has been proposed to help either reduce population through introduction of sterile insects or for population replacement. In this case, dsRNA must be first injected in the host insect. Tests are being conducted on several species with promising results but as stated by Scolari et al. (2011), there is a need to understand environmental and genetic influences when assessing the potential use of such transgenics. The transgenic method has been first used in D. melanogaster with the GAL4/UAS transgenic system that leads to the expression of hairpin RNA (Kennerdell and Carthew, 2000; Tavernarakis et al., 2000). Subsequently, transgenic technology has generated transgenic Aedes aegypti that produces dsRNA (Travanty et al., 2004). Through the use of a U6 promoter in D. Melanogaster, S2 cells can generate short hairpin RNA (shRNA) to inhibit gene expression (Wakiyama et al., 2005). RNAi molecules targeting the circadian clock gene per have also introduced into Bombyx mori embryos by a piggyback plasmid to obtain genesilenced transgenic individuals (Sandrelli et al., 2007). The transfection technique has been used to silence the D. melanogaster mitochondrial frataxin gene $d f h$, generating large-sized, long-lived larvae and short-lived adults (Sandrelli et al., 2007). The GAL4/UAS transgenic system has also been used in B. mori (Sandrelli et al., 2007) to allow for induction of the transgenic construct. Therefore, gene function can be studied within a certain time period, and the study of gene functions in development, physiology, and the nervous system is possible.

\subsection{Virus-mediated uptake}

Virus-mediated RNAi methods involve the infection of the host with viruses carrying dsRNA formed during viral replication and targeting the gene of interest in the host. For 
example, recombinant Sindbis virus introduced into B. mori cells through electroporation can produce dsRNA to inhibit $B R-C$ gene expression, causing the larvae not to pupate or leading to adult defects (Uhlirova et al., 2003). Virus-mediated RNAi studies are still rare. However, this method takes advantage of the infection and ability of the virus to spread rapidly in a host population. Virus-mediated RNAi does not require screening for transgenic insects or tissues, and thus, it has unique advantages.

\section{RNAi-based pest control}

In our struggle to minimizing the damage caused by insect pests, we have to acknowledge that pests cannot be efficiently managed by utilizing a single pest control agent. Several studies have shown that pest resistance to chemical pesticide and more recently to Bt has increased requiring new techniques to be applied to reduce the impacts of pest on crop production. While commonalities regarding the development of resistance to chemical and biological control agents remain to be determined, research suggests that both biochemical and genetic factors can contribute to this resistance. It is therefore crucial to continue examining the potential of integrated pest control or management (IPM) to reduce the threat of pests on agroecosystems. IPM has been suggested as a strategy to control incidence of pests since the 1950's and is based on six components: controlled pest populations, healthy crops, monitoring, mechanical and biological controls, and responsible use of pesticides (Kogan, 1998). The basis of for IPM is to balance ecological gain with economic loss (Southwood and Way, 1970). Over the past decade, the number of studies examining these issues has been increasing with, RNAi, as a novel pesticide-free way, to be integrated into IPM.

Research is still in its infancy to examine the application of RNAi machinery for pest control, as most of the focus has been on functional studies of insect genes. Huvenne and Smagghe (2010) however describe in some detail the potential application of RNAi in insect control through cell-line and feeding-in-plant experiments. Based on the currently available literature, they suggested five important factors largely influencing the silencing effect and the efficiency of RNAi as insect pest control technique: concentration of dsRNA, nucleotide sequence, length of dsRNA fragment, persistence of the silencing effect, and life stage of the target pest.

Through insect gene function studies involving injecting or feeding with dsRNA, we have found that some gene silencing can dramatically affect insect growth and development. Theoretically it would be possible to use RNAi to inhibit insect gene leading to insect control. Already, pest control using transgenic plants expressing dsRNA have been published (Baum et al., 2007; Mao et al., 2007). Transgenic corn expressing dsRNA against the vacuolar ATPase gene $(v-A T P)$ significantly decreases the damage caused by $D$. virgifera virgifera LeConte and, notably, protects corn crops (Baum et al., 2007). Introduction of RNAi elements targeting the CYP6AE14 gene, which is directly related to gossypol detoxification in Helicoverpa armigera, into Arabidopsis or tobacco inhibits CYP6AE14 gene expression in $H$. armigera feeding on the transgenic plants and, therefore, increases the toxicity of gossypol (Mao et al., 2007). Although there needs to be more testing in the field and at large scale, transgenic insects have also been tested as a mechanism for pest control (Scolari et al., 2011). For both transgenic plants and insects, very few species have been investigated and it is clear that further research is essential to explore the potential use of transgenics as an effective means for pest control. Like any other control mechanisms, risk assessment will be 
required to determine whether RNAi technology as a form of pest control will be safe and likely create a new era in pest control.

\section{Conclusion}

Widespread increase in the application of RNAi technology in insect research has facilitated the identification of insect gene function. Research has shown that while dsRNA is particularly conservative, there are various functions and development factors among insect species. Such variations are yet to be fully understood but certainly can serve as a basis for determining their capacity to control insect genes. The main challenge for moving towards larger scale projects remains the development of effective delivery mechanisms. Feeding is very popular in insect RNAi research and may have the most promising future in pest control, especially with the creation of transgenic plants producing dsRNA. Overtime, the use of transgenic insects will also lead to more efficient pest control.

Our understanding of the types of dsRNA and their spreading mechanisms within an organism can limit our ability to move further. Indeed, existing studies have not provided enough evidence that systemic RNAi, with silencing RNA molecules spreading throughout the entire body, can be achieved in all insects. Which insects have characteristics promoting systemic RNAi? Are the mechanisms underlying systemic RNAi the same in different insect species? Such questions need to be answered before moving further in developing large scale pest control systems. Undoubtedly, there is broad potential for the application of RNAi technology in pest control, mainly if combined into IPM strategies.

\section{Acknowledgements}

This work was supported by the National Key Project of Fundamental Scientific Research in China ("973" Programs, No. 2011CB100404), and the projects of the National Natural Science Foundation of China (No. 30871649, 30970528, and 30971925).

\section{References}

Anderson PR, Kirby K, Hilliker AJ, Phillips JP, 2005. RNAi-mediated suppression of the mitochondrial iron chaperone, frataxin, in Drosophila. Hum. Mol. Genet., 14(22): 3 397-3 405.

Arakane Y, Muthukrishnan S, Kramer KJ, Specht CA, Tomoyasu Y, Lorenzen MD, Kanost M, Beeman RW, 2005. The Tribolium chitin synthase genes TcCHS1 and TcCHS2 are specialized for synthesis of epidermal cuticle and midgut peritrophic matrix. Insect Mol. Biol., 14(5): $453-463$.

Araujo RN, Santos A, Pinto FS, Gontijo NF, Lehane MJ, Pereira MH, 2006. RNA interference of the salivary gland nitrophorin 2 in the triatomine bug Rhodnius prolixus (Hemiptera: Reduviidae) by dsRNA ingestion or injection. Insect Biochem. Mol. Biol., 36(9): 683-693.

Baum JA, Bogaert T, Clinton W, Heck GR, Feldmann P, Ilagan O, Johnson S, Plaetinck G, Munyikwa T, Pleau M, Vaughn T, Roberts J, 2007. Control of coleopteran insect pests through RNA interference. Nature Biotechnology, 25(11): 1322-1326.

Boutla A, Delidakis C, Livadaras I, Tsagris M, Tabler M, 2001. Short 5'-phosphorylated double-stranded RNAs induce RNA interference in Drosophila. Curr. Biol., 11(22): 1776-1780. 
Chen J, Zhang D, Yao Q, Zhang J, Dong X, Tian H, Chen J, Zhang W, 2010. Feeding-based RNA interference of a trehalose phosphate synthase gene in the brown planthopper, Nilaparvata lugens. Insect Molecular Biology, 19(6): 777-786.

Chen X, Tian H, Zou L, Tang B, Hu J, Zhang W, 2008. Disruption of Spodoptera exigua larval development by silencing chitin synthase gene A with RNA interference. Bulletin of Entomological Research, 98(06): 613-619.

Dai H, Ma L, Wang J, Jiang R, Wang Z, Fei J, 2008. Knockdown of ecdysis-triggering hormone gene with a binary UAS/GAL4 RNA interference system leads to lethal ecdysis deficiency in silkworm. Acta Biochimica et Biophysica Sinica, 40(9): 790-795.

Dietzl G, Chen D, Schnorrer F, Su K-C, Barinova Y, Fellner M, Gasser B, Kinsey K, Oppel S, Scheiblauer S, Couto A, Marra V, Keleman K, Dickson BJ, 2007. A genome-wide transgenic RNAi library for conditional gene inactivation in Drosophila. Nature, 448(7 150): 151-156.

Dong Y, Friedrich M, 2005. Nymphal RNAi: Systemic RNAi mediated gene knockdown in juvenile grasshopper. BMC Biotechnol., 5: 25-32.

Dzitoyeva S, Dimitrijevic N, Manev H, 2001. Intra-abdominal injection of double-stranded RNA into anesthetized adult Drosophila triggers RNA interference in the central nervous system. Mol. Psychiatry, 6(6): 665-670.

Eaton BA, Fetter RD, Davis GW, 2002. Dynactin is necessary for synapse stabilization. Neuron, 34(5): 729-741.

Ferre J, and Van Rie J, 2002. Biochemistry and genetics of insect resistance to Bacillus thuringiensis. Annu. Rev. Entomol. 47, 501-533

Fire A, Xu S, Montgomery MK, Kostas SA, Driver SE, Mello CC, 1998. Potent and specific genetic interference by double-stranded RNA in Caenorhabditis elegans. Nature, 391(6 669): 806-811.

Geley S, Müller C, 2004. RNAi: Ancient mechanism with a promising future. Exp. Gerontol., 39(7): 985-998.

Gura T, 2000. A silence that speaks volumes. Nature, 404(6 780): 804-808.

Gvakharia BO, Bebas P, Cymborowski B, Giebultowicz JM, 2003. Disruption of sperm release from insect testes by cytochalasin and beta-actin mRNA mediated interference. Cell Mol. Life Sci., 60(8): 1 744-1 751.

Hannon GJ, 2002. RNA interference. Nature, 418(6 894): 244-251.

Huvenne H, Smagghe G, 2010. Mechanisms of dsRNA uptake in insects and potential of RNAi for pest control: A review. J Insect Physiol, 56: 227 - 235.

Kennerdell JR, Carthew RW, 2000. Heritable gene silencing in Drosophila using doublestranded RNA. Nature Biotechnology, 18(8): 896-898.

Kogan M, 1998. Integrated pest management:Historical perspectives and contemporary developments. Annual Review of Entomology, 43: 243-270.

Kotwica J, Bebas P, Gvakharia BO, Giebultowicz JM, 2009. RNA interference of the period gene affects the rhythm of sperm release in moths. J. Biol. Rhythms, 24(1): 25-34.

Lee CM, Su MT, Lee HJ, 2009. Pigment dispersing factor: an output regulator of the circadian clock in the German cockroach. J. Biol. Rhythms., 24(1): 35-43.

Lipardi C, Wei Q, Paterson BM, 2001. RNAi as random degradative PCR: siRNA primers convert mRNA into dsRNAs that are degraded to generate new siRNAs. Cell, 107: 297-307.

Mao YB, Cai WJ, Wang JW, Hong GJ, Tao XY, Wang LJ, Huang YP, Chen XY, 2007. Silencing a cotton bollworm $\mathrm{P} 450$ monooxygenase gene by plant-mediated RNAi impairs larval tolerance of gossypol. Nature Biotechnology, 25(11): 1307-1 313. 
March JC, Bentley WE, 2007. RNAi-based tuning of cell cycling in Drosophila S2 cells: Effects on recombinant protein yield. Appl. Microbiol Biotechnol, 73(5): 1 128-1 135.

Martin D, Maestro O, Cruz J, Mane-Padros D, Belles X, 2006. RNAi studies reveal a conserved role for RXR in molting in the cockroach Blattella germanica. J. Insect Physiol., 52(4): 410-416.

Moriyama Y, Sakamoto T, Karpova SG, Matsumoto A, Noji S, Tomioka K, 2008. RNA interference of the clock gene period disrupts circadian rhythms in the cricket Gryllus bimaculatus. J. Biol. Rhythms, 23(4): 308-318.

Newmark PA, Reddien PW, Cebria F, Alvarado AS, 2003. Ingestion of bacterially expressed double-stranded RNA inhibits gene expression in planarians. Proceedings of the National Academy of Sciences of the United States of America, 100(90 001): 11861 - 11 865.

Niu BL, Shen WF, Liu Y, Weng HB, He LH, Mu JJ, Wu ZL, Jiang P, Tao YZ, Meng ZQ, 2008. Cloning and RNAi-mediated functional characterization of MaLac2 of the pine sawyer, Monochamus alternatus. Insect Mol. Biol., 17(3): 303-312.

Rajagopal R, Sivakumar S, Agrawal N, Malhotra P, Bhatnagar RK, 2002. Silencing of midgut aminopeptidase $\mathrm{N}$ of Spodoptera litura by double-stranded RNA establishes its role as Bacillus thuringiensis toxin receptor. J. Biol. Chem., 277(49): 46 849-46 851.

Roignant JY, Carre C, Mugat B, Szymczak D, Lepesant JA, Antoniewski C, 2003. Absence of transitive and systemic pathways allows cell-specific and isoform-specific RNAi in Drosophila. RNA, 9(3): 299-308.

Saleh M-C, Tassetto M, van Rij RP, Goic B, Gausson V, Berry B, Jacquier C, Antoniewski C, Andino R, 2009. Antiviral immunity in Drosophila requires systemic RNA interference spread. Nature, 458(7 236): 346-350.

Saleh MC, van Rij RP, Hekele A, Gillis A, Foley E, O'Farrell PH, Andino R, 2006. The endocytic pathway mediates cell entry of dsRNA to induce RNAi silencing. Nature Cell Biology, 8: $793-802$.

Sandrelli F, Cappellozza S, Benna C, Saviane A, Mastella A, Mazzotta GM, Moreau S, Pegoraro M, Piccin A, Zordan MA, Cappellozza L, Kyriacou CP, Costa R, 2007. Phenotypic effects induced by knock-down of the period clock gene in Bombyx mori. Genet. Res., 89(2): 73-84.

Schlüns H, Crozier RH, 2007. Relish regulates expression of antimicrobial peptide genes in the honeybee, Apis mellifera, shown by RNA interference. Insect Mol. Biol., 16(6): $753-759$.

Scolari F, Siciliano P, Gabrieli P, Gomulski LM, Bonomi A, Gasperi G, Malacrida AR, 2011. Safe and fit genetically modified insects for pest control: from lab to field applications. Genetica, 139: 41-52.

Siomi H, Siomi MC, 2009. On the road to reading the RNA-interference code. Nature, 457: 396 - 404.

Sumitani M, Yamamoto DS, Lee JM, Hatakeyama M, 2005. Isolation of white gene orthologue of the sawfly, Athalia rosae (Hymenoptera) and its functional analysis using RNA interference. Insect Biochem. Mol. Biol., 35(3): 231-240.

Takahashi T, Hamada A, Miyawaki K, Matsumoto Y, Mito T, Noji S, Mizunami M, 2009. Systemic RNA interference for the study of learning and memory in an insect. Journal of Neuroscience Methods, 179(1): 9-15.

Tavernarakis N, Wang SL, Dorovkov M, Ryazanov A, Driscoll M, 2000. Heritable and inducible genetic interference by double-stranded RNA encoded by transgenes. Nature Genetics, 24(2): 180-183. 
Terenius O, Papanicolaou A, Garbutt JS, et al, 2011. RNA interference in Lepidoptera: An overview of successful and unsuccessful studies and implications for experimental design. J Insect Physiol. 57: 231-245.

Tian H, Pen H, Yao Q, Chen H, Xie Q, Tang B, et al, 2009. Developmental control of a lepidopteran pest Spodoptera exigua by ingestion of bacteria expressing dsRNA of a non-midgut gene. PLoS One, 4: 1-13.

Timmons L, Fire A, 1998. Specific interference by ingested dsRNA. Nature, 395(6 705): 854.

Tomoyasu Y, Miller SC, Tomita S, Schoppmeier M, Grossmann D, Bucher G, 2008. Exploring systemic RNA interference in insects: a genome-wide survey for RNAi genes in Tribolium. Genome Biology, 9(1): R10.1-R10.22.

Travanty EA, Adelman ZN, Franz AWE, Keene KM, Beaty BJ, Blair CD, James AA, Olson $\mathrm{KE}, 2004$. Using RNA interference to develop dengue virus resistance in genetically modified Aedes aegypti. Insect Biochem. Mol. Biol., 34(7): 607-613.

Turner CT, Davy MW, MacDiarmid RM, Plummer KM, Birch NP, Newcomb RD, 2006. RNA interference in the light brown apple moth, Epiphyas postvittana (Walker) induced by double-stranded RNA feeding. Insect Mol. Biol., 15(3): 383-391.

Uhlirova M, Foy BD, Beaty BJ, Olson KE, Riddiford LM, Jindra M, 2003. Use of Sindbis virus-mediated RNA interference to demonstrate a conserved role of BroadComplex in insect metamorphosis. Proceedings of the National Academy of Sciences of the United States of America, 100(26): 15 607-15 612.

Van Roessel P, Hayward NM, Barros CS, Brand AH, 2002. Two-color GFP imaging demonstrates cell-autonomy of GAL4-driven RNA interference in Drosophila. Genesis, 34(1-2): 170-173.

Wakiyama M, Matsumoto T, Yokoyama S, 2005. Drosophila U6 promoter-driven short hairpin RNAs effectively induce RNA interference in Schneider 2 cells. Biochem. Biophys. Res. Commun., 331(4): 1 163-1 170.

Walshe DP, Lehane SM, Lehane MJ, Haines LR, 2009. Prolonged gene knockdown in the tsetse fly Glossina by feeding double stranded RNA. Insect Mol. Biol., 18(1): 11-19.

Whangbo JS, Hunter CP, 2008. Environmental RNA interference. Trends in Genetics, 24: $297-305$.

Winston WM, Molodowitch C, Hunter CP, 2002. Systemic RNAi in C. elegans requires the putative transmembrane protein SID-1. Science, 295(5 564): 2 456-2 459.

Yang ZX, Wen LZ, Wu QJ, Wang SL, Xu BY, Zhang YJ. 2008. Application of RNA interference in studying gene functions in insects. Acta Entomologia Sinica, 51(10): 1 077-1 082.

Zhao Y, Yang G, Wang-Pruski G, You M, 2008. Phyllotreta striolata (Coleoptera: Chrysomelidae): Arginine kinase cloning and RNAi-based pest control. European Journal of Entomology, 105(5): 815-812.

Zhou X, Wheeler MM, Oi FM, Scharf ME, 2008. RNA interference in the termite Reticulitermes flavipes through ingestion of double-stranded RNA. Insect Biochem. . Mol. Biol., 38(8): 805-815.

Zhu Q, Arakane Y, Beeman RW, Kramer KJ, Muthukrishnan S, 2008. Functional specialization among insect chitinase family genes revealed by RNA interference. Proceedings of the National Academy of Sciences of the United States of America, 105(18): 6 650-6 655. 


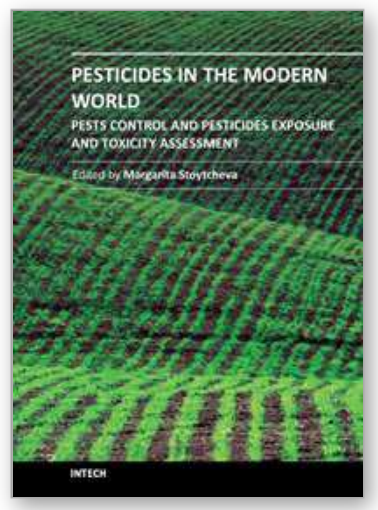

\section{Pesticides in the Modern World - Pests Control and Pesticides Exposure and Toxicity Assessment}

Edited by Dr. Margarita Stoytcheva

ISBN 978-953-307-457-3

Hard cover, 614 pages

Publisher InTech

Published online 30, September, 2011

Published in print edition September, 2011

The present book is a collection of selected original research articles and reviews providing adequate and upto-date information related to pesticides control, assessment, and toxicity. The first section covers a large spectrum of issues associated with the ecological, molecular, and biotechnological approaches to the understanding of the biological control, the mechanism of the biocontrol agents action, and the related effects. Second section provides recent information on biomarkers currently used to evaluate pesticide exposure, effects, and genetic susceptibility of a number of organisms. Some antioxidant enzymes and vitamins as biochemical markers for pesticide toxicity are examined. The inhibition of the cholinesterases as a specific biomarker for organophosphate and carbamate pesticides is commented, too. The third book section addresses to a variety of pesticides toxic effects and related issues including: the molecular mechanisms involved in pesticides-induced toxicity, fish histopathological, physiological, and DNA changes provoked by pesticides exposure, anticoagulant rodenticides mode of action, the potential of the cholinesterase inhibiting organophosphorus and carbamate pesticides, the effects of pesticides on bumblebee, spiders and scorpions, the metabolic fate of the pesticide-derived aromatic amines, etc.

\section{How to reference}

In order to correctly reference this scholarly work, feel free to copy and paste the following:

Guang Yang, Minsheng You, Liette Vasseur, Yiying Zhao and Chunhui Liu (2011). Development of RNAi in Insects and RNAi-Based Pest Control, Pesticides in the Modern World - Pests Control and Pesticides Exposure and Toxicity Assessment, Dr. Margarita Stoytcheva (Ed.), ISBN: 978-953-307-457-3, InTech, Available from: http://www.intechopen.com/books/pesticides-in-the-modern-world-pests-control-and-pesticides-exposure-andtoxicity-assessment/development-of-rnai-in-insects-and-rnai-based-pest-control

\section{INTECH}

open science | open minds

\author{
InTech Europe \\ University Campus STeP Ri \\ Slavka Krautzeka 83/A \\ 51000 Rijeka, Croatia \\ Phone: +385 (51) 770447 \\ Fax: +385 (51) 686166 \\ www.intechopen.com
}

\author{
InTech China \\ Unit 405, Office Block, Hotel Equatorial Shanghai \\ No.65, Yan An Road (West), Shanghai, 200040, China \\ 中国上海市延安西路65号上海国际贵都大饭店办公楼 405 单元 \\ Phone: +86-21-62489820 \\ Fax: +86-21-62489821
}


(C) 2011 The Author(s). Licensee IntechOpen. This chapter is distributed under the terms of the Creative Commons Attribution-NonCommercialShareAlike-3.0 License, which permits use, distribution and reproduction for non-commercial purposes, provided the original is properly cited and derivative works building on this content are distributed under the same license. 